\title{
Dissecting genetic pathways in schwannomatosis and malignant rhabdoid tumour
}

\author{
E Algar \\ From Familial Aspects of Cancer 2011 Research and Practice: A combined meeting of kConFab, Australian \\ Breast Cancer Family Study, Australian Colorectal Cancer Family Study, Australian Ovarian Cancer Study, \\ Family Cancer Clinics of Australia and New Zealand and kConFab \\ Kingscliff, Australia. 23-26 August 2011
}

Schwannomatosis is a form of Neurofibromatosis type 2 (NF2) characterized by multiple schwannomas without vestibular involvement, affecting the cranium, spine and periphery. Several recent genetic studies have implicated the SMARCB1/INI1 tumour suppressor gene in familial schwannomatosis. SMARCB1 is located centromeric to $N F 2$ on $22 \mathrm{q}$ and loss of function of SMARCB1 is also a hallmark of malignant rhabdoid tumour (MRT), a highly aggressive tumour of infancy. Both familial and sporadic schwannoma tumours show a mosaic pattern of SMARCB1 protein expression, suggestive of tumour cells either haploinsufficient, or null for SMARCB1 protein. Familial schwannomas linked to constitutional SMARCB1 mutation can also have somatic mutation of $N F 2$, and conversely, schwannoma tumours associated with constitutional NF2 mutation show mosaic loss of SMARCB1, suggesting the involvement of a four-hit mechanism. Molecular analysis for evidence of constitutional SMARCB1 mutation is important in both familial and sporadically occurring schwannomatosis because of the transmission risk for a mutation predisposing to the incurable MRT, in early childhood. However as for NF2, recent evidence suggests that constitutional SMARCB1 mutations have variable penetrance and exhibit mosaicism, highlighting the importance of examining multiple tumour tissue samples as well as blood in affected individuals to ascertain germline predisposition and to provide accurate counseling for transmission risk. Further studies are needed to define the SMARCB1 mutation spectrum in schwannomatosis and to dissect the strikingly different biology between schwannoma and MRT.

Correspondence: elizabeth.algar@rch.org.au

Molecular Oncology Laboratory, Murdoch Children's Research Institute, Royal Children's Hospital, Flemington Rd, Parkville, 3052, Australia
Published: 12 April 2012

doi:10.1186/1897-4287-10-S2-A8

Cite this article as: Algar: Dissecting genetic pathways in

schwannomatosis and malignant rhabdoid tumour. Hereditary Cancer in Clinical Practice 2012 10(Suppl 2):A8.

Submit your next manuscript to BioMed Central and take full advantage of:

- Convenient online submission

- Thorough peer review

- No space constraints or color figure charges

- Immediate publication on acceptance

- Inclusion in PubMed, CAS, Scopus and Google Scholar

- Research which is freely available for redistribution

Submit your manuscript at www.biomedcentral.com/submit
( Biomed Central 